\title{
SEM OBSERVATIONS OF POLLEN GRAINS, FRUITS AND SEEDS OF THE PIENINY MOUNTAINS (SOUTH POLAND) ENDEMIC SPECIES ERYSIMUM PIENINICUM (ZAPAŁ.) PAWŁ. (BRASSICACEAE)
}

\author{
IRMinA MACIEJEWSKA-RUTKOWSKA ${ }^{1}$, LESZEK BEDNORZ ${ }^{2}$, TOSHIYUKI FUJIKI ${ }^{3}$ \\ ${ }^{1}$ Department of Forest Botany, August Cieszkowski Agricultural University \\ Wojska Polskiego 71 D, 60-625 Poznań, Poland \\ e-mail: irminamr@au.poznan.pl \\ 2 Department of Botany, August Cieszkowski Agricultural University \\ Wojska Polskiego 71 C, 60-625 Poznań, Poland \\ ${ }^{3}$ Nagoya University, Graduate School of Environmental Studies, School of Sciences \\ Furo-cho, Chikusa-ku Nagoya City, 464-8601 Japan
}

(Received: June 22, 2006. Accepted: August 31, 2006)

\begin{abstract}
Erysimum pieninicum (Zapał.) Pawł. (Brassicaceae) is an endemic species, growing only in Pieniny Mts. The aim of the presented work was to investigate its pollen morphology as well as its ultrastructural traits of pericarp and seed-coat. Pollen grains of this species were of small size, 3-zonocolpate with reticulate ornamentation. The external siliqua surface was of rugose sculpture, covered by numerous, stellate hairs. The internal surface of the fruit was naked and characterized by striate sculpture. The seed-coat ornamentation of E. pieninicum was of blister type.
\end{abstract}

KEY WORDS: Erysimum pieninicum, endemic species, pollen morphology, fruit morphology, seed morphology, SEM.

\section{INTRODUCTION}

According to Koch and others (2003) Erysimum is taxonomically one of the most difficult genus of the mustard family (Brassicaceae) and extensive phylogenetic studies on this taxon are necessary. It comprises many taxa of uncertain status and the total number of described species oscillates between 80 and 180 (Latowski 1975; Koch et al. 1.c). Whereas the taxonomy of the genus has traditionally been based on a rather small number of characters, such as annual versus perennial life cycles, some macroscopic traits of flowers and fruits, leaf architecture or trichome morphology, their application does not always allow to distinguish some closely related species (Latowski 1985; Ball 1993).

With reference to different representatives of Brassicaceae, the search for distinct and unequivocal indicators prompted some botanists to examine seed morphology and anatomy (e.g. Vaughan and Whitehouse 1971; Latowski 1975; Garnock-Jones 1991; Koul et al. 2000; Brown et al. 2004; Zeng at al. 2004). As regards seed anatomy, Vaughan and Whitehouse (1.c.) noticed that testa may be of greatest value in determining taxonomic relationships within the mustard family. However, Latowski (1.c.) analyzing both morphological and anatomical traits of seeds of all Polish Erysimum species with the use of light microscope, was not able to clearly separate some taxa. The use of electron microscope (SEM) may resolve many systematic questions. For example the study of Koul and others (1.c.) on the Brassica and allied genera supported the use of seed coat microsculpture pattern as a parameter for species identification. Detailed investigations on the anatomy of the chazal endosperm cyst of 11 genera of Brassicaceae (Brown et al. 1.c.) also showed the potential taxonomic value of this feature.

The ultrastructural patterns of the pericarp in mustard family have not been recognized yet. Similarly, there still lack SEM studies of pollen morphology of most the Brassicaceae species. According to the authors' knowledge, only pollen grains of several species of Erysimum were observed under the scanning electron microscope (see Anchev and Deneva 1997; Perveen et al. 2004; Halbritter 2006).

Hence, the aim of the present work was to investigate the pollen morphology of Erysimum pieninicum, as well as the ultrastructural traits of siliqua pericarp and seed-coat.

Since the taxonomic revision carried out by Pawłowski (1946), this taxon has been distinguished in the rank of species, however sometimes it is included in Erysimum hungaricum sensu lato, together with E. wahlenbergii (Ball 
1993). Among the nine species of wallflower noted in Poland, this one belongs to the rarest. It is an endemic species, growing only in Pieniny Mts., altitude 500-790 $\mathrm{m}$ a.s.1., on four sites. The species is listed in Bern Convention on the Conservation of European Widelife and Natural Habitats and it is protected by law in Poland. Still in 2001 Kaźmierczakowa and Zarzycki considered E. pieninicum to be a threatened species of the Polish vascular flora, while Zarzycki and Szelag (2006) include it to the group of rare plants in Poland.

\section{MATERIALS AND METHODS}

In 2005 the flowers and the fruits of Erysimum pieninicum were collected from two natural localities of Pieniny Mts: the hill of the Czorsztyn castle (E 20 19', N 49 26', $550 \mathrm{~m}$ a.s.1.) and slopes of Flaki Mt. (E 20 $21^{\prime}$, $\mathrm{N} 49^{\circ} 25^{\prime}$, $790 \mathrm{~m}$ a.s.1.). Two samples of pollen grains (ripe anthers were taken only) were acetolysed according to Erdtman's method (1952), with some insignificant modifications (Tomlik-Wyremblewska 1995). The samples of fruits and seeds (properly developed and ripe) were not prepared, but only cleaned. The use of scanning electron microscopes (JEOL JSM 6300 and LEO 435 VP) allowed to investigate the details of exine sculpture and the silique and seed ultrastructure. Light microscopy (BIOLAR 2308) was mainly carried out to study the exine structure and quantitative characters of pollen grains. In all 60 pollen grains of two samples were observed. The pollen terminology follows Hoen (1999) and Halbritter and others (2006). With regard to the seeds and fruits, terminology of Barthlott (1981), based on SEM observations of epidermal and seed coat surface in 5000 species of seed plants, was applied.

\section{RESULTS}

\section{Pollen morphology (Figs 1-2)}

In this study pollen grains of Erysimum pieninicum were of small size; on average length of polar axis (P) was 18.00 $\mu \mathrm{m}$ (with the whole range 15.00-21.00 $\mu \mathrm{m}$ ) and equatorial axis (E) $17.25 \mu \mathrm{m}$ (with the whole range 13.50-19.50 $\mu \mathrm{m}$ ). $\mathrm{P} / \mathrm{E}$ value oscillated from 0.91 to 1.30 , with the mean value 1.05. The grains were most often spheroidal in shape (54.6\% of observed grains), sometimes prolate spheroidal $(33.3 \%)$, rarely subprolate $(7.6 \%)$ or oblate spheroidal $(4.5 \%)$; with equatorial outline circular or lobate.

Three-zonocolpate, sporadically four-zonocolpate pollen grains were observed. Colpi were usually comparatively narrow and deeply sunken in exine, with acute ends. Aperture length was more than $4 / 5$ length of polar axis. Colpus margin was regular, membrana colpi granulate.

Exine always consisted of two layers, well visible in LM. Usually ectexine and endexine were of the same thickness. Exine of medium thickness - 1.5-2.0 $\mu$ m thick.

All grains were with tectum perforatum and with reticulate type of ornamentation. Lumina of different size, \pm izodiametric, tetragonal or pentagonal, with obtuse angles or \pm circular. Muri built by single rows of columellae, with rounded edges. Sometimes there were visible 2-3 bacula on the bottom of lumina. Sculpture of apocolpi and mesocolpi similar, but the lumina of apocolpi rather smaller.

\section{Siliqua morphology (Fig. 3)}

The fruit morphology of Erysimum pieninicum was described with the use of LM by Latowski (1975). According to this author the siliquas of this species are on the average 40-60 $\mathrm{mm}$ long and $1.5 \mathrm{~mm}$ wide, linear, with rhombic outline of cross-section. The base of fruit is rounded and the apex is acute, with the beak, consisting stigma, 1.1-2.0 mm long. The stigma is distinctly bilobate, wider than beak. Fruit usually sparsely hairy, sometimes densly. Hairs stellate. Valves with only midvein distinct. The septum is membranous, naked, of the same thickness, as the valves.

The current study of the fruit ultrastrastructure revealed the external surface of the valve to be rugose with irregular, relatively shallow wrinkles. The cells of the outer layer were izodiametric, \pm polygonal or rounded, with the slightly protruding latteral walls and with somewhat concave outer ones, but the cell outlines were rather weakly marked. Instead, at high magnification (at least 200x) the layer of striate cuticule, consisting of the striae running parallel to the fruit axis, was visible. The surface was covered by stellate, three- or four-armed, rarely two-armed hairs; with the diameter about 100-200 $\mu \mathrm{m}$. The arms were curved and gradually tapered, with acute ends. The hairs of pimple texture, with granules of different size. Additionally, there were scattered rod-like elements, no more than $10 \mu \mathrm{m}$ high and stomata, $\pm 15 \mu \mathrm{m}$ long. The inner surface of valve was of striatae sculpture. The cells were izodiametric, \pm rounded, with outer walls convex and lateral ones concave and often undulate-sinuate. The inner surface was also covered by thin layer of rugulate cuticule, without hairs or pores. The septum surface was rugose. The outline of cells of the outer layer was rather poorly marked. There was no pubescence on the surface of septum, with the exception of its lateral edge, sometimes with the single, stellate hairs.

\section{Seed morphology (Fig. 4)}

According to Latowski (1975), the seeds of the species of Erysimum develop from campylotropous ovules. The mature seeds of $E$. pieninicum are $\pm 1,81-2,40 \mathrm{~mm}$ long and $0,81-0,90 \mathrm{~mm}$ wide; laterally flattened, variable in outline: oblong elliptical, oval or almost rectangular, with gently rounded angles. The seed apex is straight or obliquely truncate, with the protruding radicle. At the same level there is also visible a blackish spot, enclosing hilum in the form of fine membrane, sometimes with the rest of funicle. The base of seed may be obliquely acute or gently rounded, with the patch-like wing, 300-500 $\mu \mathrm{m}$ long. Seed-coat 50-100 $\mu \mathrm{m}$ thick, consisting of 3-4 layers. Testa cells are polygonal in outline, at cross-section with mucilaginous excrescences, mushroom-shaped, up to $20(-35) \mu \mathrm{m}$ high.

The present investigation of seed ultrastructure of Erysimum piennicum revealed the blister type of seed-coat sculpture. The cells of the testa were izodiametric, pentaor hexagonal, sometimes almost circular in outline. The central parts of outer walls were markedly swelled, forming small proturberances with gently rounded and pited apices. Additionally, their sides were covered with the wrinkles, of radial arrangement in relation to the swelling. Each blister was surrounded by a shallow depression, limited by the protruding roll, built by the lateral walls of the cells of the seed-coat. 

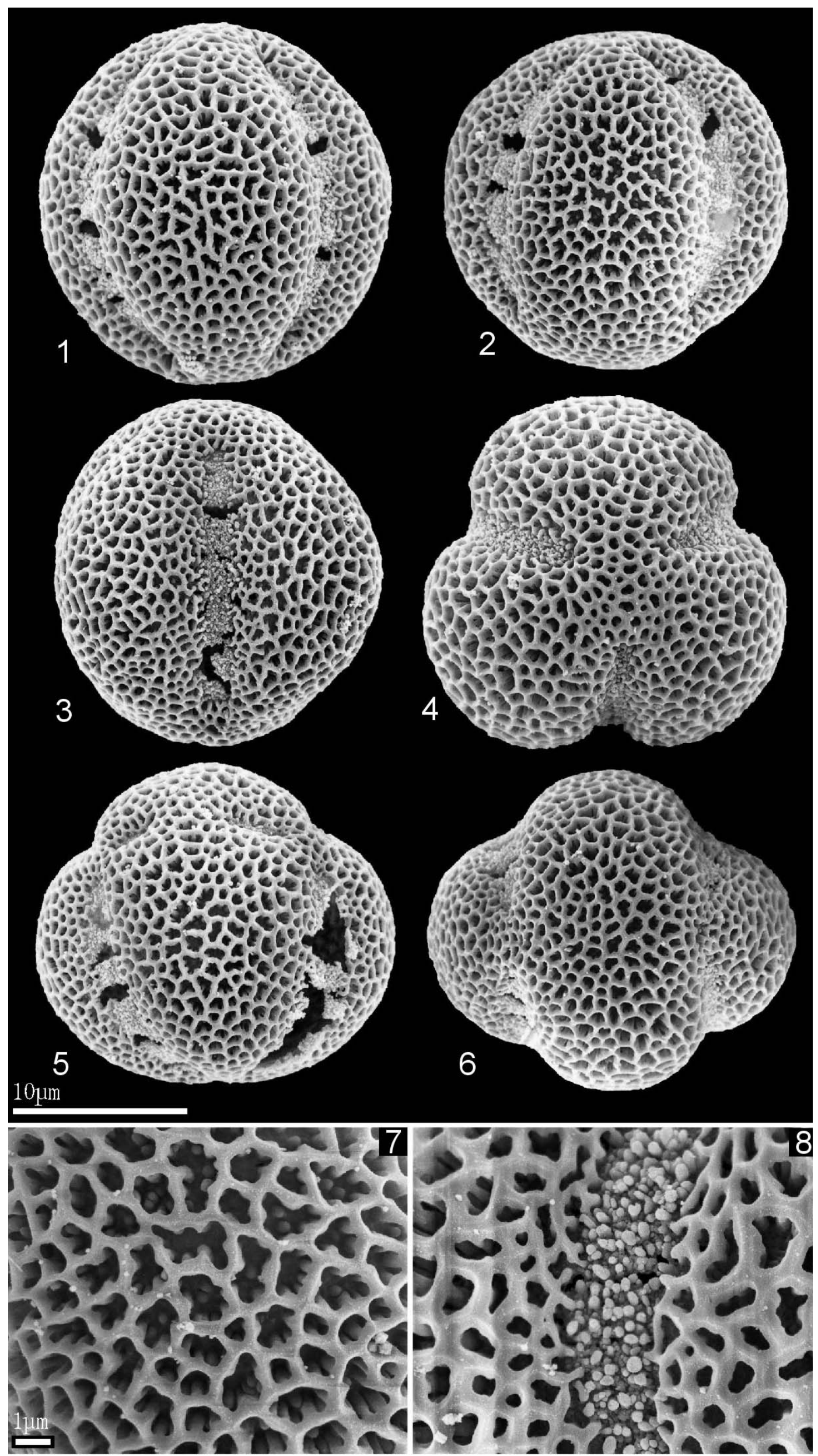

Fig. 1. Pollen morphology of Erysimum pieninicum in SEM: 1-3 - colpi and reticulate ornamentation of mesocolpi visible; 4 - outline in polar view, reticulate ornamentation of apocolpus visible; 5-6 - grains in oblique positions, both with mesoand apocolpium; 7 - details of reticulate ornamentation; 8 - granulate membrane of colpus. 

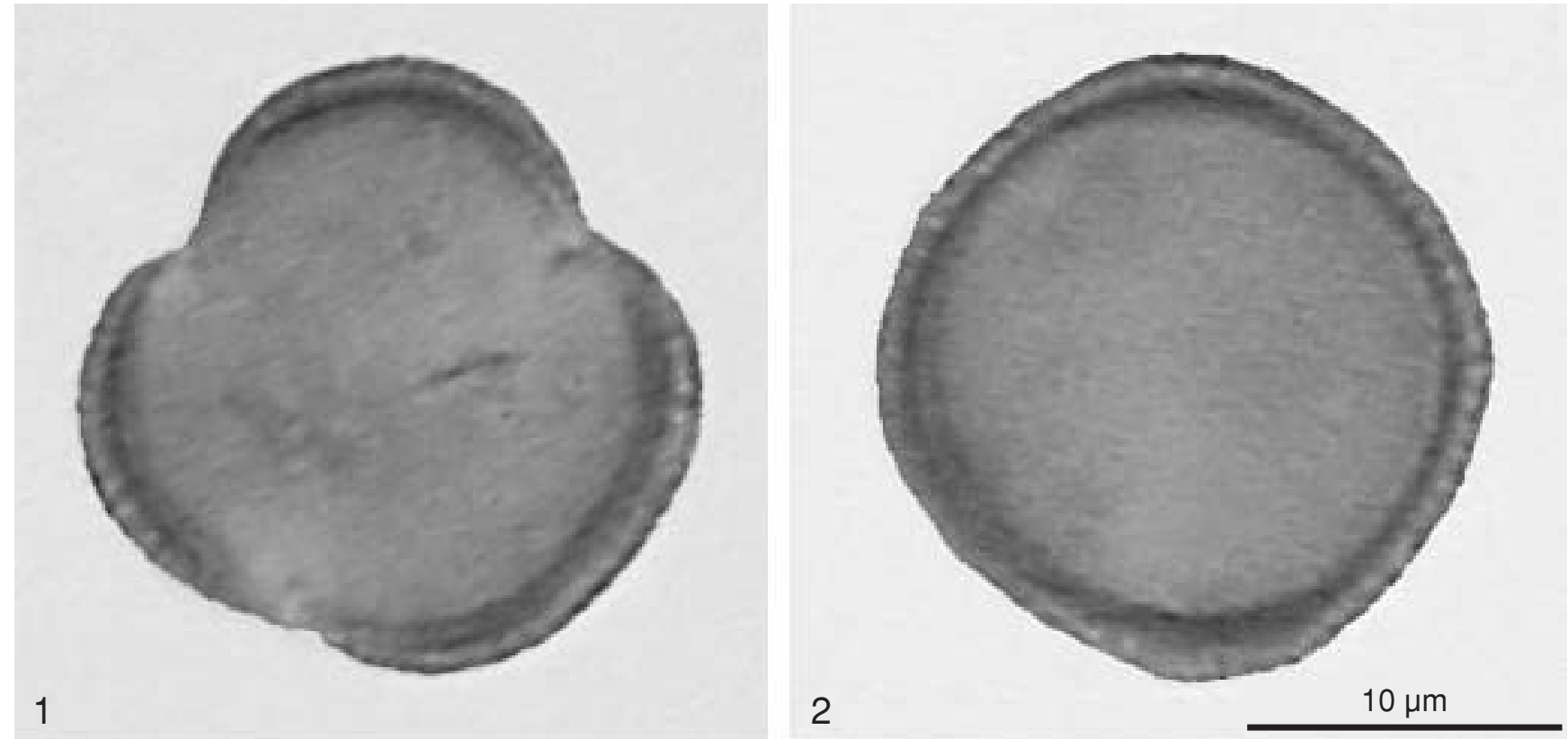

Fig. 2. Pollen morphology of Erysimum pieninicum in LM: 1 - outline in polar view, exine structure visible; $\mathbf{2}$ - outline in equatorial view, exine structure visible.
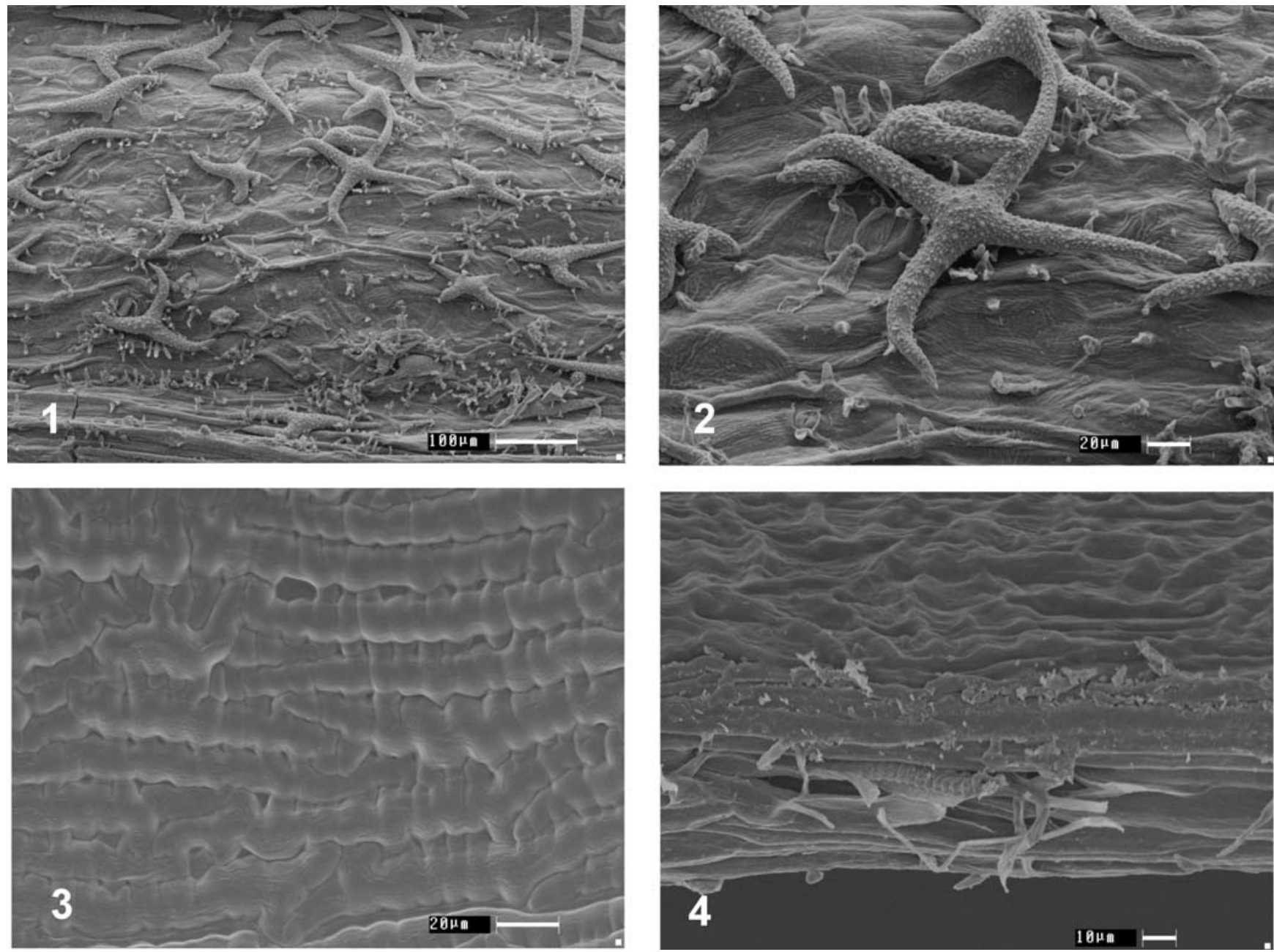

Fig. 3. Ultrastructure of siliqua of Erysimum pieninicum: 1 - rugose ornamentation of external surface of valve, covered by stellate hairs; scattered pores also visible; $\mathbf{2}$ - close-up of the stellate hair, pimple texture visible; $\mathbf{3}$ - striate ornamentation of internal surface of valve; $\mathbf{4}$ - rugose ornamentation of septum.

\section{DISCUSSION}

This study shows that pollen grains of Erysimum pieninicum present the typical structure, characteristic for the other nine European species of the genus, that have been investigated before (Anchev and Deneva 1997; Halbritter 2006). They are always trizonocolpate and with reticulate ornamentation. However some differences may be noticed. 

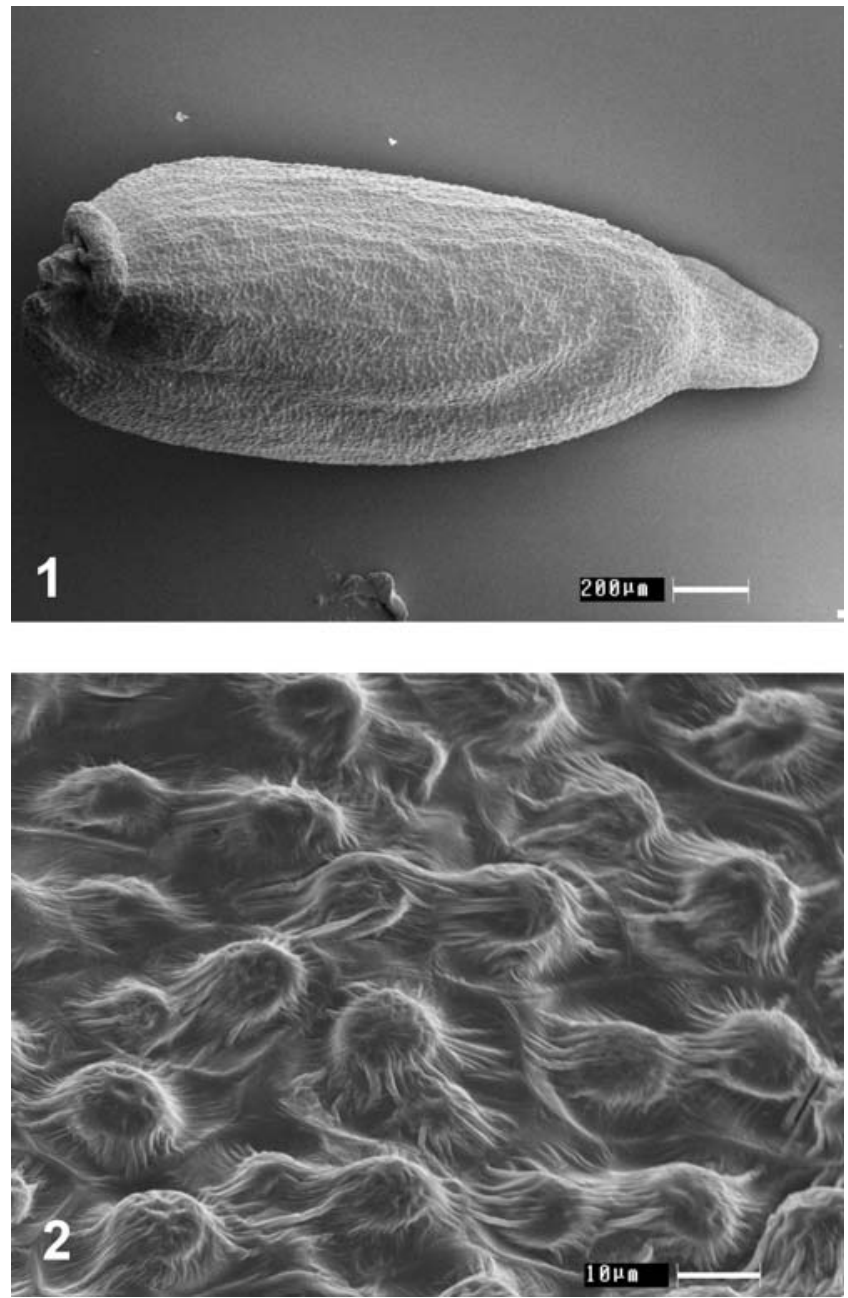

Fig. 4. Ultrastructure of seed of Erysimum pieninicum: $\mathbf{1}$ - outline of the whole seed; hilum and patch-like wing well visible; $\mathbf{2}$ - blister ornamentation of seed-coat.

The pollen grains of Bulgarian species described by Anchev and Deneva (1.c.; 6 taxa) have the lumina of reticulum equal in size or smaller than the muri, whereas the grains of E. pieninicum are characterized by lumina of diameter larger than muri. Then the reticulum traits of the three Erysimum species (E. odoratum, E. sylvestre and E. repandum) studied by Halbritter (1.c.) are very similar to the grains of $E$. pieninicum. There are only slight differences between $E$. pieninicum and E. repandum, concerning the ultrastructure of muri. The muri of the former species have smooth edges, whereas the murus edges of the latter are coarse.

According to Latowski (1975) all seeds of Polish species of the genus Erysimum are very variable with respect to the outline and their differentiation may be difficult. That is why the cited author puts the seeds of E. pieninicum together with the related species: E. durum, E. hieraciifolium, $E$. hungaricum, E. virgatum and E. wahlenbergii, as one morphological type. Similarly, the cited author does not mark out the sillique of E. pieninicum from the fruits of $E$. virgatum, E. wahlenbergii and E. hungaricum.

The present SEM study on Erysimum pieninicum shows some details of pollen as well as of fruit and seed morphology, which may be specific only for this species. However, further studies on the ultrastructure of allied species, specially on E. wahlenbergii, should be carried out. They may be helpful in determination of the systematic position of E. pieninicum: whether it is a separate taxon or it rather should be included to E. hungaricum species complex, as suggested by Ball (1993).

\section{AKNOWLEDGEMENTS}

We would like to thank the following persons: Dr Grzegorz Vončina (Pieniny National Park) for collecting plant material, Dr Hanna Jackowiak (Agricultural University, Poznań) for taking microphotographs of seeds and fruits, Dr Dariusz J. Gwiazdowicz and Mirosław Dziurla (both Agricultural University, Poznań) for preparing pictures.

\section{LITERATURE CITED}

ANCHEV M., DENEVA B. 1997 Pollen morphology of seventeen species from family Brassicaceae (Cruciferae). Phytologia Balcanica 3/2, 3: 75-82.

BALL P.W. 1993. Erysimum L. In: T.G. Tutin, N.A. Burges, A.O. Charter, J.R. Edmondson, V.H. Heywood, D.M. Moore, D.H. Valentine, S.M. Walters, D.A. Webb (eds). Flora Europaea. Psilotaceae to Platanaceae. 1. $2^{\text {nd }}$ edition, Cambridge University Press: 325-335.

BARTHLOTT W. 1981. Epidermal and seed surface characters of plants: systematic applicability and some evolutionary aspects. Nord. J. Bot. 1: 345-355.

BROWN R.C., LEMMON B.E., NGUYEN H. 2004. Comparative anatomy of the chalazal endosperm cyst in seeds of the Brassicaceae. Bot. J. Linn. Soc. 144: 375-394.

ERDTMAN G. 1952. Pollen Morphology and Plant Taxonomy. Angiosperms. An introduction to palynology 1. Almqvist \& Wiksell, Stockholm.

GARNOCK-JONES P.J. 1991. Seed morphology and anatomy of the New Zealand genera Cheesemania, Ischnocarpus, Iti, Notothlaspi, and Pachycladon (Brassicaceae) New Zealand J. Bot. 29: 71-82.

HALBRITTER H. 2000. Erysimum odoratum, E. repandum, E. sylvestre (Brassicaceae). In: R. Buchner, M. Weber. Paltdat a palynological database: Descriptions, illustrations identification and information retrieval. http://www.paldat.org/

HALBRITTER H., WEBER M., ZETTER R., FROSCH-RADIVO A., BUCHNER R., HESSE M. 2006. Paldat - illustrated handbook of pollen terminology. Vienna. $61 \mathrm{pp}$. http://www. palat.org

HOEN P. 1999. Glossary of Pollen and Spore Terminology. http://www.bio.uu.nl/ palaeo/glossary/index.htm

KAŹMIERCZAKOWA R., ZARZYCKI K. 2001. Polska czerwona księga roślin. Paprotniki i rośliny kwiatowe. Instytut Botaniki im. W. Szafera, Polska Akademia Nauk, Kraków. (in Polish with English summary)

KOCH M., AL-SHEHBAZ IH.A., MUMMENHOFF K. 2003. Molecular systematics, evolution, and population biology in the mustard family (Brassicaceae). Ann. Miss. Bot. Gard. 90: 151-171.

KOUL K.K., NAGPAL R., RAINA S.N. 2000. Seed coat microsculpturing in Brassica and allied genera (subtribes Brassicinae, Raphaninae, Moricandiinae) Ann. Bot. 86, 2: 385-397.

LATOWSKI K. 1975. Badania nad morfologią i anatomią owoców i nasion środkowoeuropejskich gatunków rodzaju Erysimum L. Monogr. Bot. 49: 5-78. (in Polish with English summary)

LATOWSKI K. 1985. Erysimum L., Pszonak. In: A. Jasiewicz (ed.) Flora Polski. Rośliny naczyniowe. $2^{\text {nd }}$ edition, PAN, Inst. Botaniki PWN, Warszawa, 4: 149-159. (in Polish with English summary) 
PAWŁOWSKI B. 1946. De Erysimis carpaticis, Erisimo hieracifolio L. affinibus. Acta Soc. Bot. Pol. 17: 95-128. (in Polish with English summary)

PERVEEN A., QAISER M., KHAN R. 2004. Pollen flora of Pakistan - 62. Brassicaceae. Pak. J. Bot. 36, 4: 683-700.

TOMLIK-WYREMBLEWSKA A. 1995. Pollen morphology of genus Rubus L. I. Introductory studies of the European representatives of the subgenus Rubus L. Acta Soc. Bot. Pol. 64, 2: 187-203.
VAUGHAN J.G.; WHITEHOUSE J.M. 1971. Seed structure and the taxonomy of the Cruciferae. Bot. J. Linn. Soc. 64: 383-409.

ZARZYCKI K., SZELĄG Z. 2006. Red list of vascular plants in Poland. In: Z. Mirek, K. Zarzycki, W. Wojewoda, Z. Szeląg (eds). Red lists of plants and fungi in Poland. W. Szafer Institute of Botany, Polish Academy of Sciences, Kraków: 9-20

ZENG CH.L., WANG J.B., LIU A.H., WU X.M. 2004. Seed coat microsculpturing changes during seed development in diploid and amphidiploid Brassica species. Ann. Bot. 93: 555-566. 